\title{
FROG TAGGING: A METHOD OF STUDYING ANURAN LIFE HABITS
}

\author{
By C. M. Breder, JR.
}

WITH THE COLLABORATION OF

Ruth B. Breder and Albert C. Redmond

(Figs. 266-277 incl.)

\section{INTRODUCTION}

As our knowledge of any group of animals increases the desirability of devising new methods or of applying old ones in new ways becomes more evident. This we must do in order to extend our information along an ever increasing front and to avoid degenerating into puttering in comparatively barren fields. This becomes especially patent in the pursuit of experimental zoology and more particularly so in experimental field zoology. Work on the life histories and habits of anurans in tropical America along conventional lines brought this thought home most forcibly to the senior author. While little was done at that time along unorthodox lines, various methods of attack on innumerable fascinating problems constantly suggested themselves. One of the indirect outgrowths of such thoughts, the possibility of applying some methods of marking individual frogs, under natural conditions, in a manner somewhat similar to that employed by ornithologists in "banding" birds has developed into the present studies.

Although the work has been of but a single season the great promise of valuable results prompts us to place on record the efforts of the year in this direction, partly because of their intrinsic value, but more especially in the hope of interesting others more fortunately situated than ourselves for the further pursuit of such problems.

The senior author, has been extremely fortunate in securing the collaboration of Ruth B. Breder and Albert C. Redmond in these studies for parts of the season. Indeed most of the field work has been done by them. As they worked in different localities the paper divides readily into two chief parts accordingly. The interpretation of the data gathered by these two collaborators in which they both took active part entitles them to co-authorship. While assuming responsibility for the assembly of the data, any credit is due to R. B. Breder for the accumulation and interpretation of the data 
gathered at Haskell, N. J., and to Albert C. Redmond for that gathered at Palisades Interstate Park.

We are greatly indebted to Mr. James Brooks for his kindness in allowing the use of his camp (Camp Thomas Brooks) and land at Haskell, N. J., for these experiments and studies, and equally so to Dr. Frank E. Lutz of the American Museum of Natural History for the extension of similar privileges at the Station for the study of insects in the Harriman section of Palisades Interstate Park, N. Y., of which he has charge. In addition we are indebted to Dr. Lutz for his generosity in allowing his assistant, Albert C. Redmond, to devote a liberal portion of his time to the problem.

\section{USE OF THE METHOD}

To crystallize the reasons for developing this method and to point out some of its possible applications there are tabulated herewith a few problems to which it opens a ready lane of approach. None of these are definitely answered in the present paper for the work has not been carried on long enough, but we have every reason to believe that their solution may be in part, if not entirely, attained by this means.

1. Normal rates of growth of specimens under different types of habitat.

2. Speed of color changes and its extent in normal specimens in correlation with seasons and general environmental conditions of a normal sort.

3. Movements to and from spawning areas with reference to mass and individual movement, and its speed as correlated with sex, environmental factors, etc.

4. Movements not directly connected with breeding activity, as correlated with factors of environment; migrations.

5. Homing instinct, extent developed, variation between species and finally how it operates.

6. Learning and memory of paths and routes under normal conditions.

Some of these problems have been attacked in various ways, mostly by laboratory methods, but no work appears to have been done on the behavior of frogs in a ferral condition such as is made possible by the use of this method. Many other problems suggest themselves, such as the number of females a single male will mate 
with in one season, the constancy of voice variations and so on. If work can be carried on over several successive seasons many other additional problems at once come to mind that are well worth working out.

\section{Technique}

The basic technique for marking, tagging or banding frogs was worked out in 1924 in the jungles of Darien, Panama on a large and interesting tree frog, Hyla rosenbergii Boulenger. After various systems and methods were tried with varying degrees of success and failure it became evident that some method employing the circling of the narrowest part of the body, the "waist" of the frog would be the eventual solution. Hylas in general are especially suited to this method on account of the extreme narrowness of the region. Other forms, lacking such extreme constriction, as many Ranas, are troublesome at times, often being able to slip out of bands so placed. $R$. sylvatica has given particular bother in this regard. However, if the band is properly attached there is scant chance of even this species casting it off.

The marker or tag basically consists of a cord passed around the frog, tied in a square knot below and attached to a symbol of some sort above. Several different types were used súccessfully. They are described herewith.

Cardboard Tags.--Small cards with numbers and letters were used with considerable satisfaction. Most of them were typed as is indicated in Fig.266, A and B. The letter forms the basis for the distinction of a series and could serve to keep the frogs of different but adjacent workers distinct. The cards could carry numbers up to 99,999 by placing numbers on either side of the letter, as well as below it. A good durable paper or light card was used which had been waterproofed after punching and lettering. Most of them were dipped in liquid celluloid made by dissolving old photographic film in acetone. Such cards generally lasted up to about three months. While it was not given a really fair trial we believe sodium silicate would prove to be more satisfactory than celluloid for this purpose. A soft light fish line was found to be quite satisfactory for attachment, evidently far outlasting the cards. Several methods of attaching the card were employed as suggested by Fig. 266, A and B.

Metal Tags.-Small squares of aluminum with smooth edges and 
rounded corners were stamped with letter punches with the expectation of having them carry over into a second season. They were attached by means of durable enameled trout line. While time is not yet sufficient to report on their durability we have but little doubt that they will serve the purpose well. See Figure 266, C.
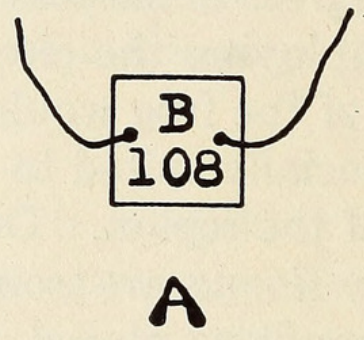
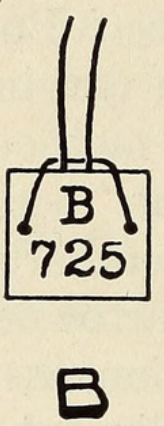
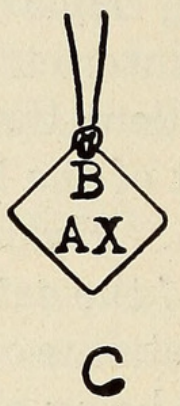

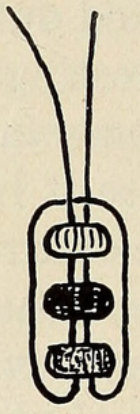

D

Fig. 266. Types of tages; A and B-Card tags; C-Metal tag; D-Bead tag.

Beads.-Differentially colored glass beads of small size were used on very small frogs. Aside from the fact that they were rather difficult to find in the field they served the purpose very well. Fine bead silk was used to attach them to the frogs. Six different colors gave the possibility of a lengthy series by using up to three beads to a frog. See Fig. 266, D for attachment methods.

Tag Holder.-Holders of light cardboard were provided with holes to take the strings already attached to the tags. Fig. 267 shows the three types of tags in their holders. A heavy open end envelope was provided to hold them. The additional effort of placing the tags in these holders was found to be more than offset by the convenience in the field. The envelope also held a short rule, a small note book a pencil and blunt nosed scissors. The entire equipment could thus be carried in an inside coat pocket.

Records.-A loose leaf note book with a page size of $5^{\prime \prime}$ by $8^{\prime \prime}$ was found to be quite satisfactory for records. Every tagged frog was given a new page, headed with its tag number, species and other primary data. Then followed the data concerning it and its recoveries in chronological order. A sample heading is indicated below. 


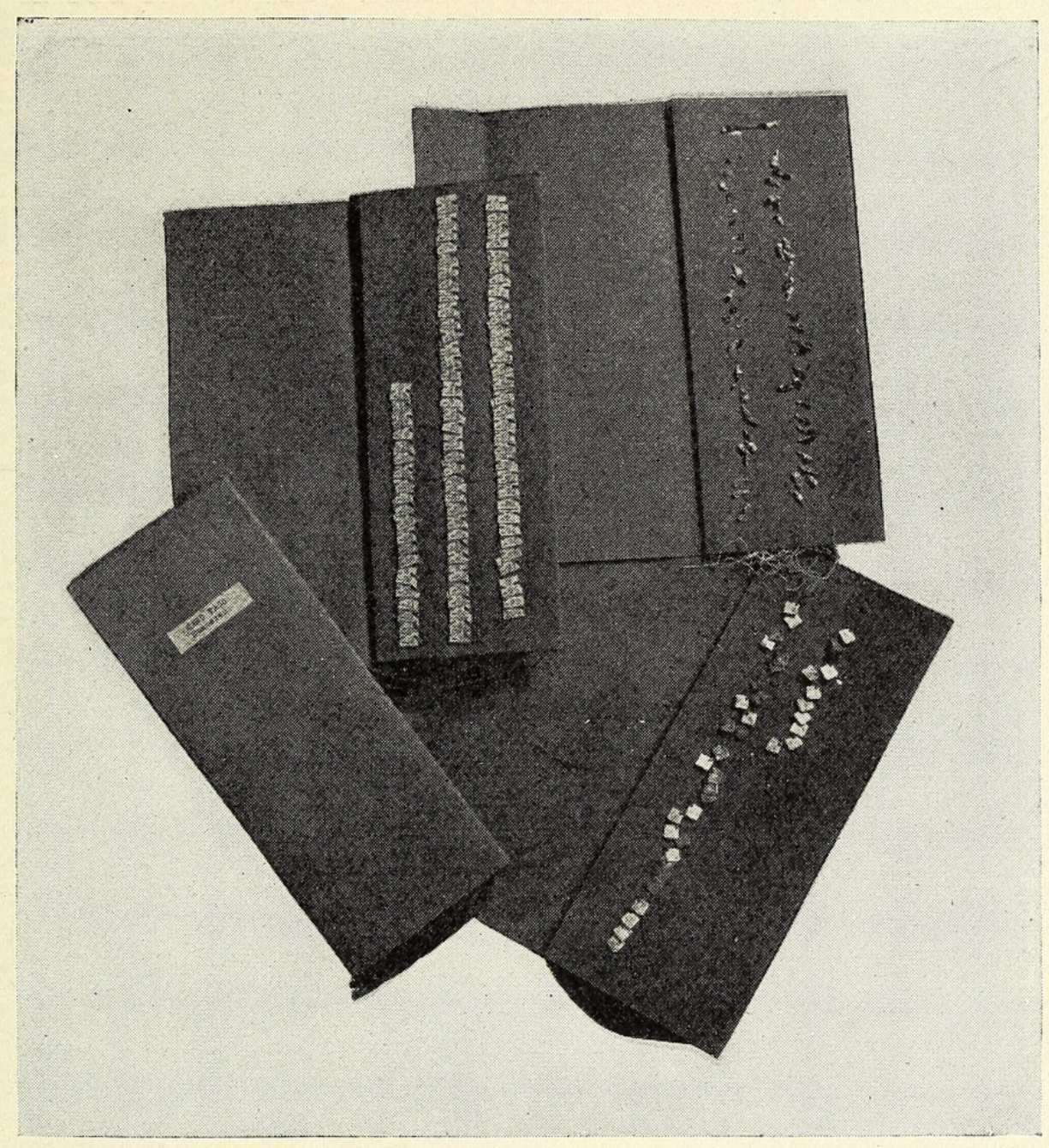

Fig. 267. Three types of tags in their holders.

$$
\text { B-104 }
$$

\section{Rana calmatans}

Interstate Park

May 6, 1926-male, $50 \mathrm{~mm}$. In pool "A" 11:20 A.M. Gave vent to more noise when handled than is usual for this species.

May 7, same place as when first seen, 9:30 A.M.

This data together with the usual field journal preserved all the required information.

Attaching the Tag.-With two operators working together it is, of course, extremely simple to attach such tags, but when one is working alone it requires some skill to make a satisfactory attachment. There seems to be no especial method to suggest, a little practice soon developing a proper deftness. The loop of string around the "waist" should just be tight enough to prevent it 


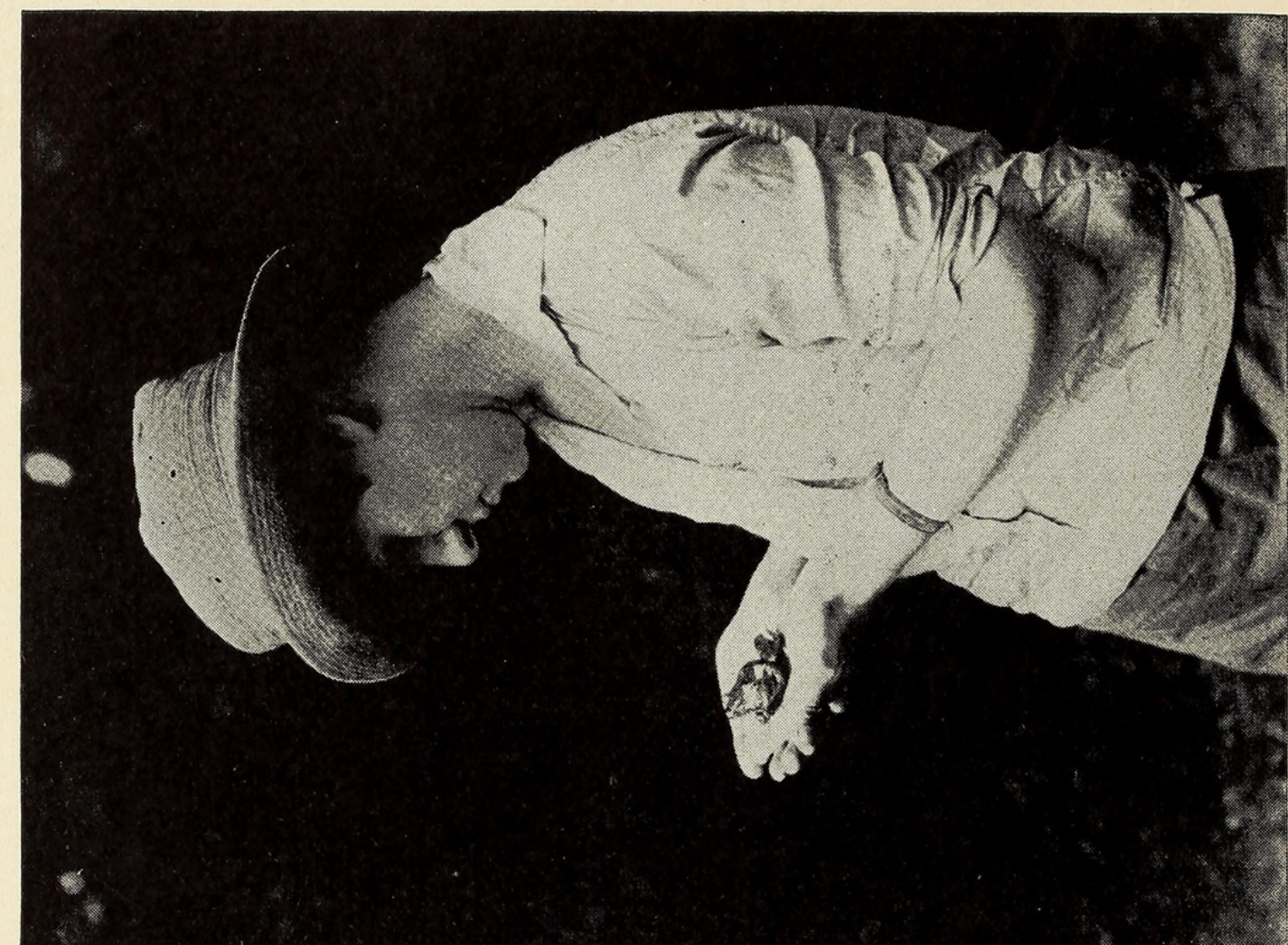

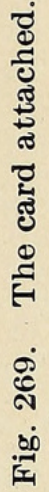

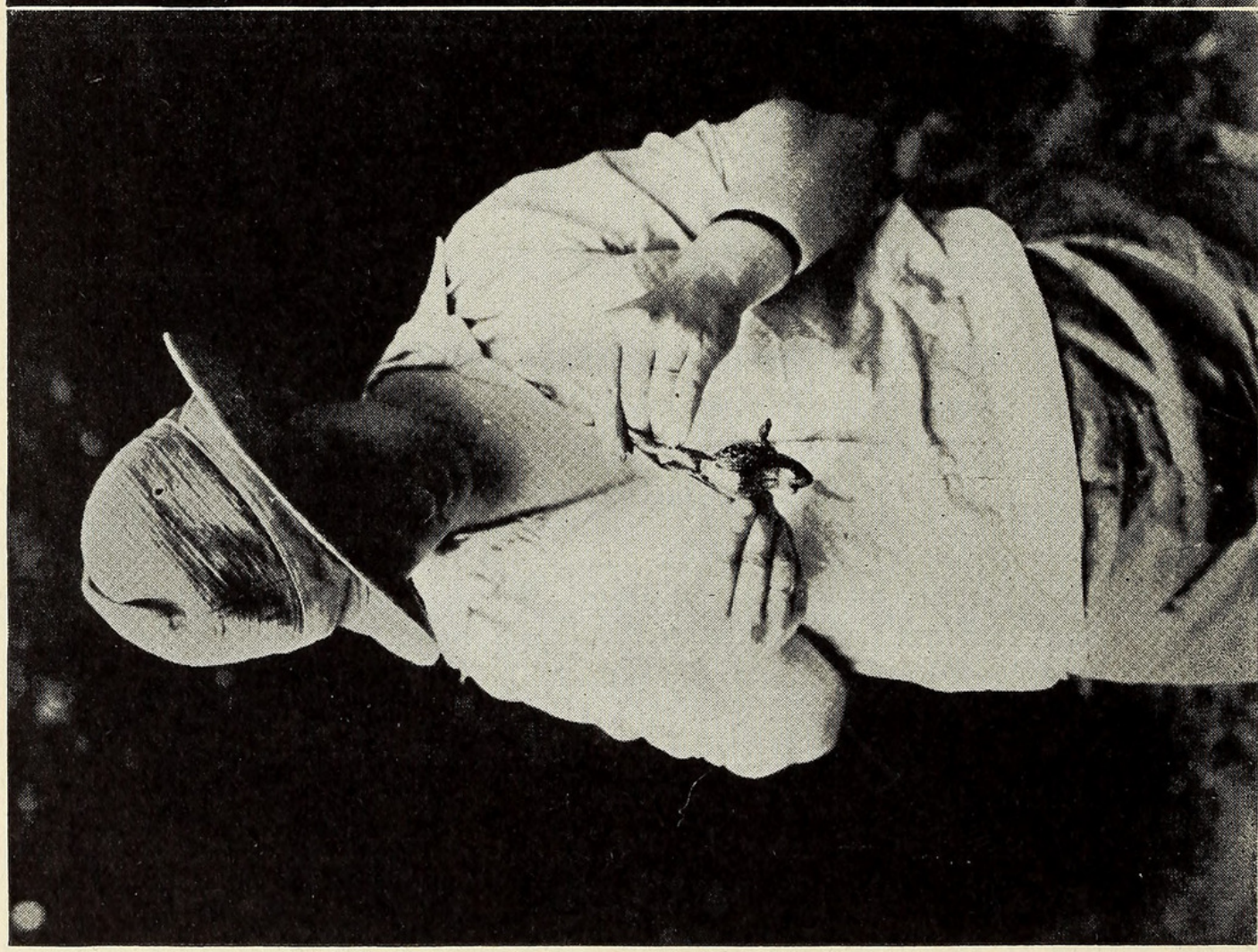

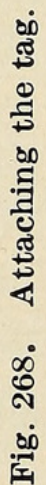


being slipped off, as some Ranas ( $R$. sylvatica, $R$. clamatans, $R$. palustris) are very apt to do, although they generally desist after two or three unsuccessful trials. In cases where it is too tight it wears through and produces sore spots. However, such injuries heal rapidly and grow over the offending cord shortly burying it with no noticeable ill effect on the animal. This can hardly be avoided in some cases where a frog is growing rapidly and observations are infrequent. It should be recalled, however, that often frogs will puff themselves up when handled so that a tag that appears to be quite tight when being tied is actually relatively loose when the frog returns to normal size. Figs. 268 and 269 show stages in the attachment of a tag.

Recaptures.-After once tagging a frog every attempt was made not to disturb it any more than necessary. Recapture was resorted to only when the tag could not be readily deciphered as it lay, i.e. when hidden by a leaf or covered with mud. A great assistance in such reading was found in the new Bausch and Loumb telemagnifier permitting a reading at distances much further than those which might cause the frog to leap away. However, it was found that a very close approach could often be made, in fact much closer than necessary, as indicated by Figs. 270 and 271.

\section{The Studies in New Jersey}

The operations at Haskell, N. J., carried out largely by R. B. Breder, were commenced on July 29 and concluded on September 26 , by which date fall weather had set in and the frogs were seeking and for most part finding hibernation, as observations a week later demonstrated. It is to be regretted that it was impossible to begin work here earlier in the season and also that the summer was unusually cool and rainy. As a consequence the stream banks were frequently flooded, often causing even Rana clamatans to seek shelter from the pelting rain and the generally disturbed conditions. Doubtless, their behavior was somewhat abnormal for this time of year.

The species and numbers of individuals tagged were as follows: Rana clamatans 61 , Rana palustris 12 , Rana sylvatica 7 , Bufo fowleri 9 , total 89. Rana clamatans, only, was tagged in sufficient numbers and recovered often enough to show any results of value. This is partly because of its dominance as a species here and partly because it was given nearly sole attention. 

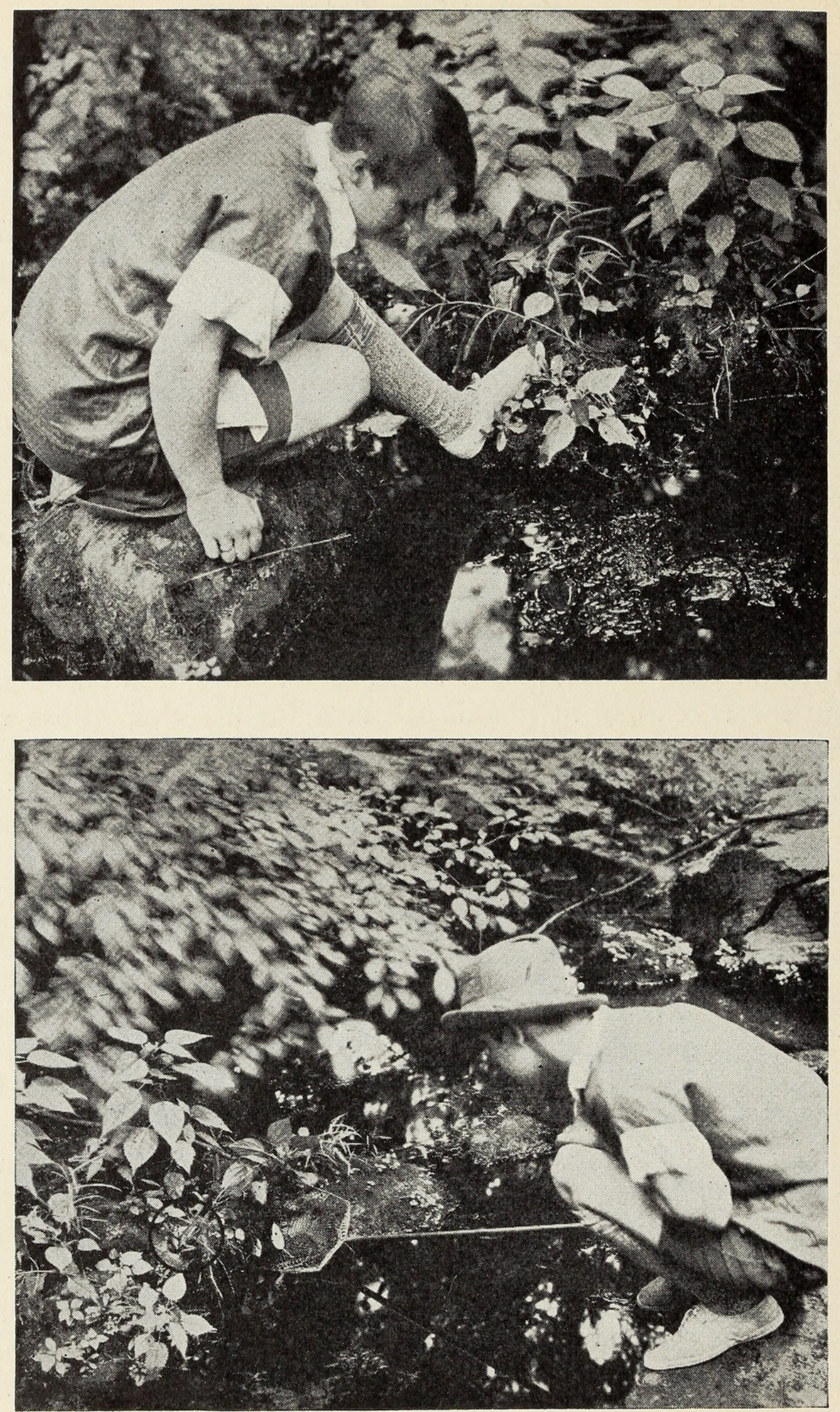

Fig. 270. Locating a tagged frog. Frog in lower right hand corner; in circle. Fig. 271. Locating a tagged frog. Frog in lower left hand corner; in circle. 


\section{Rana clamatans}

As a preliminary to a study of the extent of the homing instinct in Rana clamatans all specimens tagged here were released at places other than where taken. Sixty-onewere so treated. Of this number three were known to cast their tags shortly thereafter, the loose tags being found the next day. This leaves fifty-eight to be considered. Of this number fifty-one were taken along Post Brook and released at the camp. Of these, twenty-two were seen at some later date along the brook, leaving twenty-nine which were not seen again. The interpretation of the data supplied by these fifty-one frogs is open to some possible divergence of opinion. Such questions as the following naturally arise. As the land sloped from the camp to the brook and as it was the nearest body of water would it not be natural for the frogs to gravitate to it by simply moving down hill? This question is subsequently answered. Of those which were not recovered, how many got back to the brook and were simply not seen again, how many cast off their tags enroute, how many were intercepted by enemies and how many went elsewhere? These questions cannot all be answered satisfactorily at this time, but further work should help to clear the matter considerably. At any event a relatively large number $(43 \%)$ got back to approximately their "home" region. However, this movement can all be interpreted without calling in any "homing instinct." They moved directly away from camp in most cases and in none tarried into the second day. This was true even in spite of the large amount of rain which one might expect to lessen the urge for them to seek water. Nevertheless, they all retreated from the camp (because of the occupants ?) and it is tempting to suppose that they all started for the nearest water. Why were not more recovered?

Now let us examine another case. Three frogs were taken in the spring and released at the camp. In six and seven days respectively two (B-70 and 71) were back in the spring whilst the third was not recovered. In order to attain the spring it was necessary for them to cross the brook which proved so attractive to the frogs which were originally taken from it and to ascend the opposite bank for an approximately equal distance to reach the rather small hillside spring hole. Here is a clear case where we cannot ascribe their movements to simply tumbling down hill to the nearest puddle.

Take still another case where two frogs from the brook were 
released in the spring. One was not seen again but the other $(\mathrm{B}-22)$ returned to the brook in six days after resting two in the spring. Why was the spring not satisfactory to these two individuals when it was so desirable to the previous two that they crossed the brook to attain it when at least one of the present went to the brook? As these two experiments were in progress simultaneously we cannot ascribe it to changing conditions. Surely here we have some sort of simple homing instinct.

The statistical data of these experiments is given in Table 1, and Fig. 272 shows the location of the work with the important points indicated. The dates in the first part of Table 1 represent all those on which careful searches of the region were made. The localities indicated represent all those where frogs were released. In other words there were recoveries from each spot of releasing. With further tabulations of this sort we believe that some valuable statistical studies might be made. Sex and size is not indicated for the figures show no correlation. With a larger number of examples

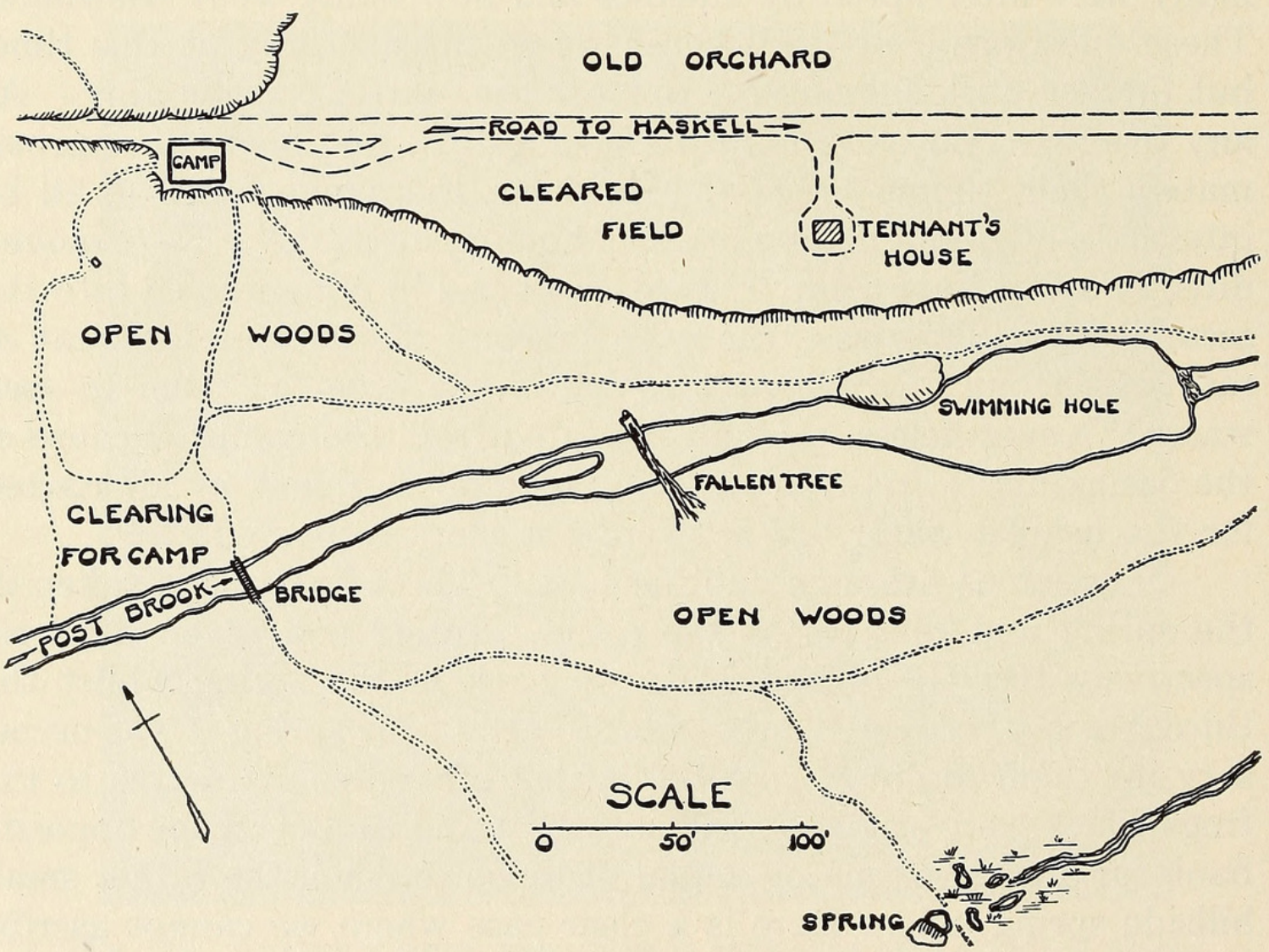

Fig. 272. Sketch map of the camp at Haskell, New Jersey, showing important localities. 
TABLE NO. 1-Recoveries of Rana clamatans

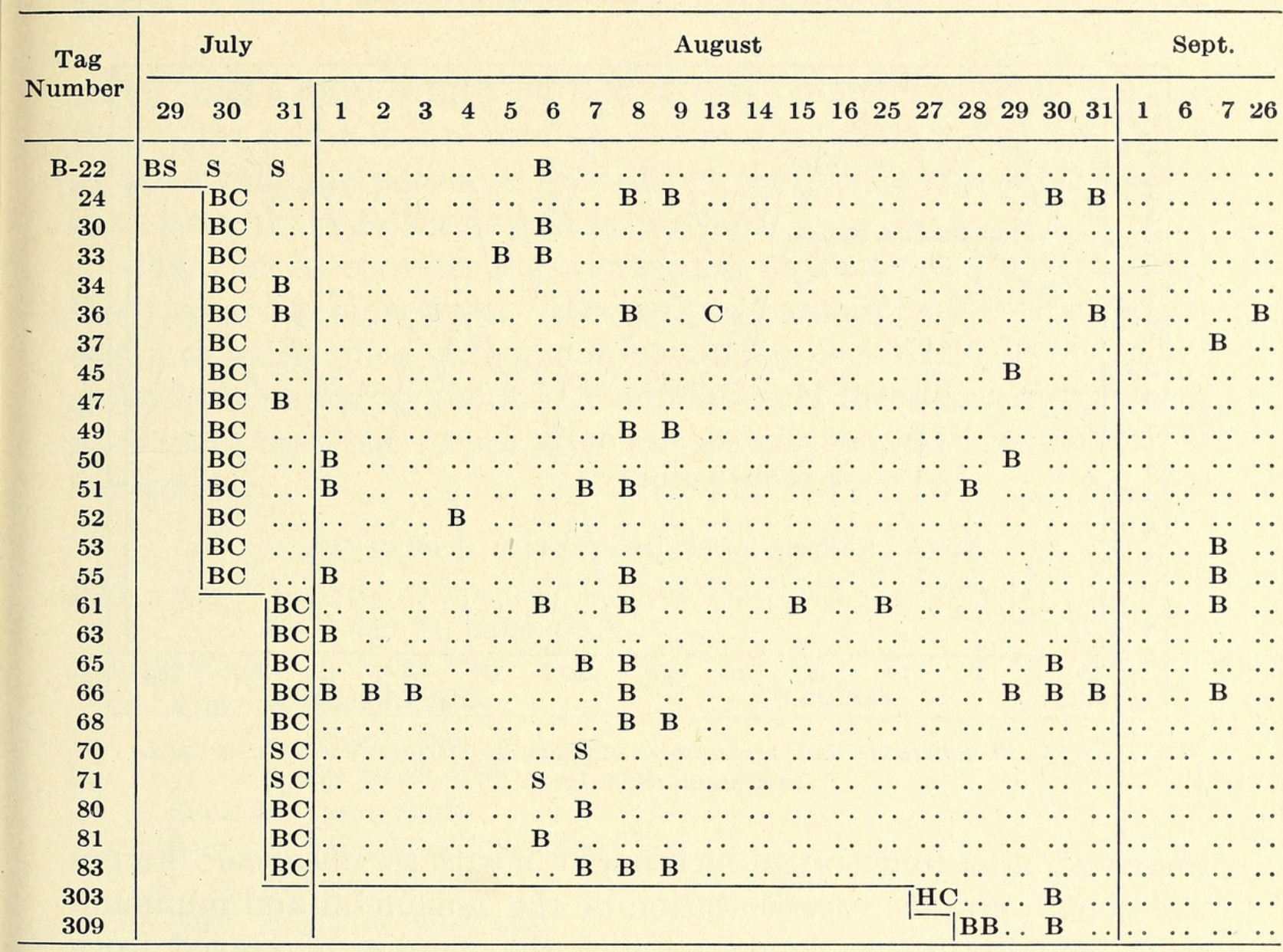

B-Brook. C-Camp. H-Halfway between B and C. S-Spring. Two localities under a date indicate those from which and to which the individual had been moved at the time of tagging

Number of recoveries of the 61 specimens tagged

\begin{tabular}{lllllllll|lll}
\hline Times recovered & 0 & 1 & 2 & 3 & 4 & 5 & 8 & Average no. of recoveries $2+$ \\
\hline No. of examples & 34 & 14 & 4 & 4 & 2 & 2 & 1 & Total no. recovered 27 \\
\hline
\end{tabular}

Intervals in days between taggings and last observations

\begin{tabular}{|c|c|c|c|c|c|c|c|c|c|c|c|c|c|c|}
\hline No. of days elapsed . . . . . . . . . . . . . & 2 & 3 & 5 & 6 & 7 & 8 & 9 & 10 & 29 & 30 & 32 & 38 & 39 & 58 \\
\hline No. of examples. & 1 & 1 & 1 & 2 & 4 & $\mathbf{1}$ & 2 & 1 & 1 & 3 & 1 & 2 & 3 & 1 \\
\hline
\end{tabular}

Average number of days............

Extent of observations-25 days of actual field work July 29 to Sept. 26 inclusive July August

\begin{tabular}{|c|c|c|c|c|c|c|c|c|c|}
\hline Dates of tagging & 29 & 30 & 31 & 6 & 7 & 27 & 28 & 29 & \\
\hline Remaining no. of days & 59 & 58 & 57 & 51 & 50 & 30 & 29 & 28 & Totals \\
\hline No. of frogs tagged & 2 & 31 & 21 & 2 & 1 & 2 & 1 & 1 & Total no. tagged . . . . . . . . 61 \\
\hline No. later recovered & 1 & 14 & 10 & $\mathbf{0}$ & $\mathbf{0}$ & 1 & 1 & 0 & Total no. recovered . . . . . . . . . 27 \\
\hline No. not recovered & 1 & 17 & 11 & 2 & 1 & 1 & $\mathbf{0}$ & 1 & Total not recovered . . . . . . . . . 34 \\
\hline
\end{tabular}




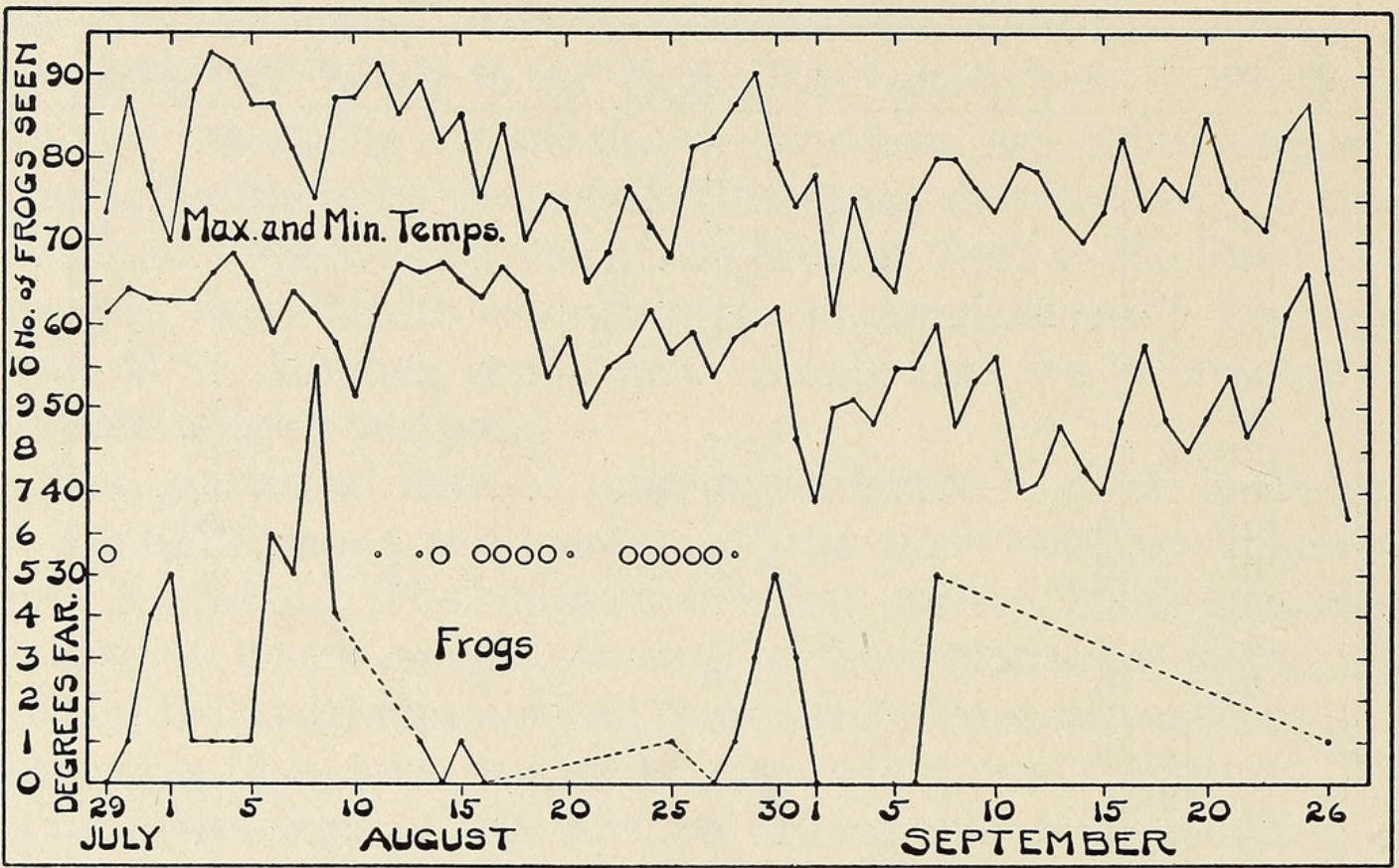

Fig. 273. Temperature (air) and number of tagged Rana clamatans seen, by days, at Haskell, New Jersey.

these and other items might be brought in with significance. Figure 273 gives a graphic representation of the maximum and minimum daily temperatures as compared with the number of tagged frogs seen. There seems to be some correlation although, of course, the data is much too slight to prove any point, it being presented more as an indication of what might yield results when further data are collected. Other matters of statistical significance we believe to be present in Table I waiting on a greater array of data to yield results.

Of the twenty-one frogs taken at the brook and released at the camp that found their way back we find from studying Table I that the average number of days between their release and recapture at the brook was 9 . This data may be arrayed as below:

$\begin{array}{lrrrrrrrrr}\text { Days elapsed } & 1 & 2 & 5 & 6 & 7 & 8 & 9 & 30 & 39 \\ \text { No. of examples } & 5 & 3 & 1 & 2 & 4 & 1 & 2 & 1 & 2\end{array}$

Thus $23 \%$ of the individuals we know got back to the brook the next day at the latest. How many more did and were not seen until later is still a question. As the four other recoveries (B-22, 70, 71 and 303) returned to their "home" sites in 6, 7,6 and 3 days respectively and as the average of the remaining twenty-one, as above 
noted, was 9 days it may be that average number of days spent in the return was not far from six. The remaining one B-309 taken at the swimming hole and released at the bridge was retaken two days later at the fallen tree (Aug. 28-30).

Now let us consider the wanderings of the frogs after attaining their apparent objectives. Here a great amount of diversification was met with, some individuals remaining constantly in one place and others scattering about. A tabulation of those specimens which gave more than one record after release may serve to indicate their movements.

MOVEMENTS AFTER RETURNING TO THE BROOK

B-24 Aug. 8, Within a few feet of where first taken (by bridge).

9,30 and 31 , Same place.

B-36 July 31 , By fallen tree.

Aug. 8, Same place.

13, Near camp.

31 , By fallen tree.

Sept. 26, Same place.

B-49 Aug. 8, Far end of fallen tree.

9, Same place.

B-50 Aug. 1, Below fallen tree.

29, At bridge.

B-51 Aug. 1, Swimming hole.

7, 8 and 28 , Same place.

B-55 Aug. 1, By fallen tree.

8 , Same place

Sept. 7, Swimming hole.

B-61 Aug. 6, By bridge.

8,15 and 25, Same place.

Sept. 7, Swimming hole.

B-65 Aug. 7, By bridge.

8 , and 30 , Same place.

B-66 Aug. 1, By fallen tree.

2 , and 3 , Same place (exact spot).

8 , and 29, Slightly below fallen tree (released at bridge).

30 , Half way between bridge and fallen tree.

31 , Three-quarters way to fallen tree.

Sept. 7, Swimming hole.

B-68 Aug. 8, Far end of fallen tree.

9, Same place.

B-83 Aug. 7, Half way between bridge and fallen tree.

8 , and 9 , Same place.

Of these eleven frogs, six were subsequently seen only in single 
small areas in any case not exceeding a radius of ten feet from where first seen after release. In other words they each stayed in a restricted region. Of the others, one (B-36) traveled up to camp and then returned, of itself, to the spot previously seen, again showing a good sense of direction. Three traveled down stream in late August and early September. One (B-66) after having been carried a short distance up stream took from August 29 to September 7 to travel from the bridge to the swimming hole. Another (B-30) traveled up stream from below the fallen tree to the bridge between August 1 and 29. It is to be noted that of those which moved about at all (the only ones, save one, seen on September 7 and including all of those which had moved down stream) were to be found at the swimming hole on that date and the one which had not moved had been there all along. Only one tagged frog was seen thereafter (September 26). Might this not be interpreted as a movement to the closest pool for purposes of hibernation? This pool is rather quiet and deep in the middle and is the only nearby place that is not in imminent danger of rapid and thorough freezing. The rather scattered data here presented seems all to point the general conclusion that these frogs have a well developed sense of direction, although when left alone are given to rather indiscriminate slight wanderings, five out of eleven moving about of their own volition.

\section{OTHER SPECIES}

A Rana sylvatica and $R$. palustris taken in the orchard on August 28, and released at the barn were next seen at the swimming hole on August 29-30 and August 31, respectively.

Three Bufo fowleri tagged near the camp were all retaken at no great distance or significant direction therefrom. The dates follow.

$\begin{array}{lll}\text { B-59 } & \text { July } 30 & \text {-August } 11 \\ \text { B-60 } & \text { July } 30 & \text {-July } 31 \\ \text { B-93 } & \text { August } 4 & \text {-August } 11\end{array}$

The Studies IN New York

The operations at Palisades Interstate Park, N. Y., carried out largely by Albert C. Redmond, were commenced on May 6 and concluded August 26. Rain and coolness interfered with activities at this locality also but the larger number tagged and more intensive methods allowed of a proportionally greater record. 
The species and number of individuals tagged were as follows. Rana clamatans 96, Rana palustris 7, Rana catesbiana 6, Rana sylvatica 1, Bufo fowleri 34, Bufo americanus 3, total 147. Rana clamatans is here also the dominant anuran and although useful data were collected on Bufo fowleri the greater mass of it refers to the former.

\section{Rana clamatans}

Methods employed here centered not so much on the homing instinct of the species, although of the fifty-six recoveries eight had originally been transplanted to other sites. The data they furnish corroborate the results obtained in New Jersey very well. Exactly half of those found their way back to their "home" localities. In these experiments the frogs were not placed at points lacking water but were transferred from one stream-side pool to another, in all of which frogs were living and were of such a nature that it would be almost humanly impossible to ascribe an advantage of one over the other as far as the "tastes" of frogs are concerned. The days elapsed between their last observation at the site of planting and their return to the "home" puddle may be expressed as below. See also Fig. 274 .

\section{B-111 May $8 \mathrm{D}$ to B June $13 \mathrm{D}$ days elapsed 35 B-112 May 6 C to B June $13 \mathrm{C}$ days elapsed 37 B-116 May $6 \mathrm{D}$ to B June $13 \mathrm{D}$ days elapsed 37 B-118 May $7 \mathrm{C}$ to B June $13 \mathrm{C}$ days elapsed 36}

It is highly probable that they returned much sooner than the "days elapsed" would seem to indicate as there is a great hiatus in the observations here (May 10 to June 12). It is to be especially noted by comparison with Fig. 274 that the pools "B," "C" and " D" are all in line and for B-111 and 116 to attain " $\mathrm{D}$ " they had to pass " $C$ " which was very close and similar to it. Nevertheless, these frogs sorted themselves out according to their origins. When the New Jersey data is compared with this and it is recalled that there the one recovered that had been taken from the brook to the spring lingered two days it seems fair to infer that placing in a relatively unfriendly environment not only gives greater impetus to departure but also increases the urge to go "home" for otherwise how could one account for the two examples crossing the brook in the New Jersey studies so comparatively rapidly? One other frog which was moved later than its tagging date (B-128), June 26-27, returned at once. 


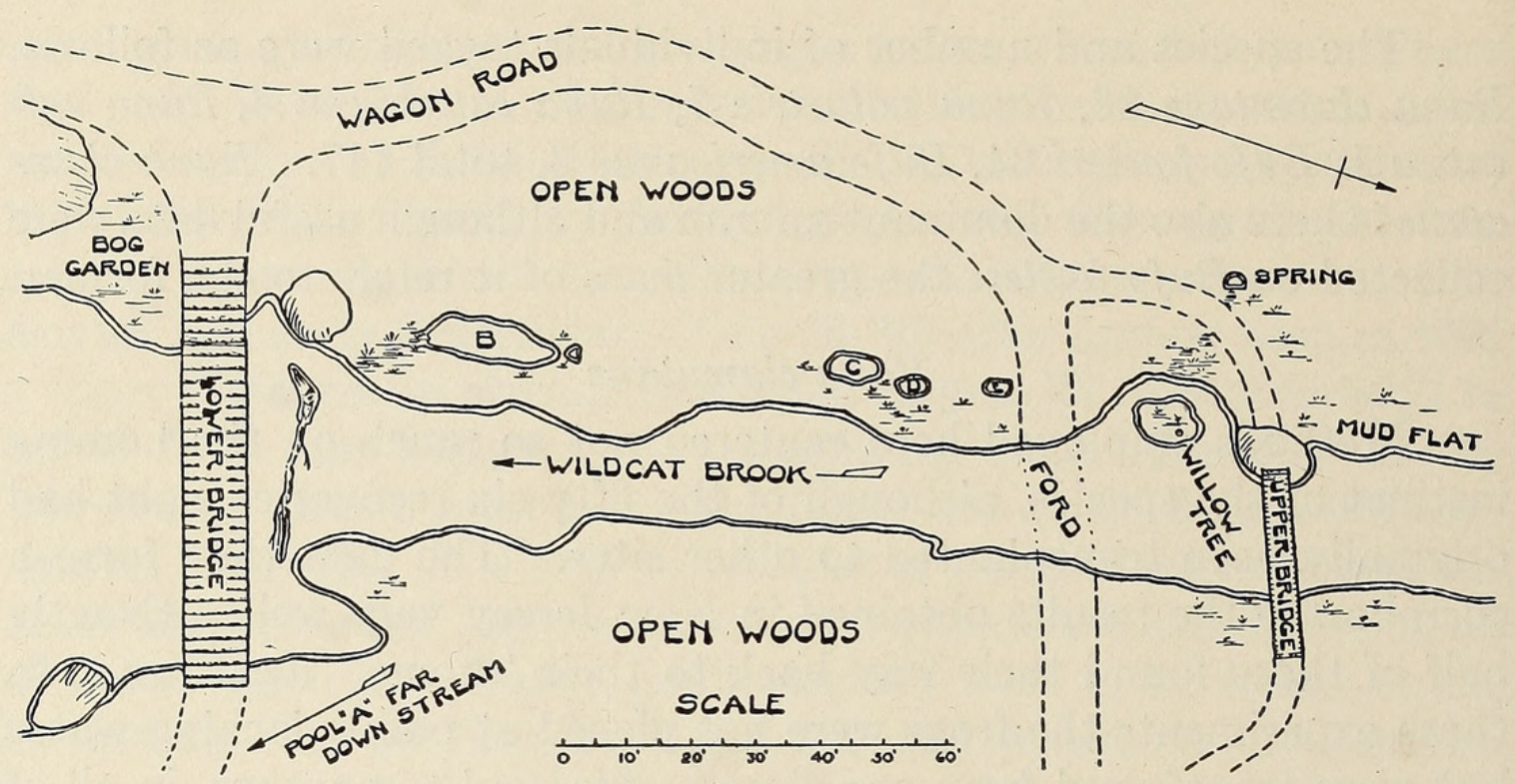

Fig. 274. Sketch map of Wildcat Brook showing important localities.

Considering the voluntary movements of these frogs which was the more special object of study at this locality we again have a great expression of individuality to deal with, more apparent here on account of the greater number of observations. Those which showed voluntary movements (omitting those transported) may be tabulated as follows:
B-105 May 6 In pool "A."
May 7 Same place. (See Fig. 275-C.)
June 21 In brook opposite "A."
July 1 Same place.
B-106 May 6 In pool "A."
May 7 Same place. (See Fig. 275-C.)
May 8 In brook opposite pool "B."
B-116 June 18 In pool " $C$ " (had returned to " $D$ " on June 13).
July 19 At ford, above pool "E" 8:00 A.M.
At willow tree 11:00 A.M.
B-128 June 12 In spring.
June 13 In brook opposite spring.
June 14 In spring (identical to previous position).
June 15 In brook opposite spring.
June 19 Ten feet down stream from last date.
June 20 Same place.
June 23 In spring.
June 25 At willow tree. (See Fig. 275-A.)
June 26 Same place. (Released on other side of brook.)
June 27 At willow tree.
July 30 Same place. 


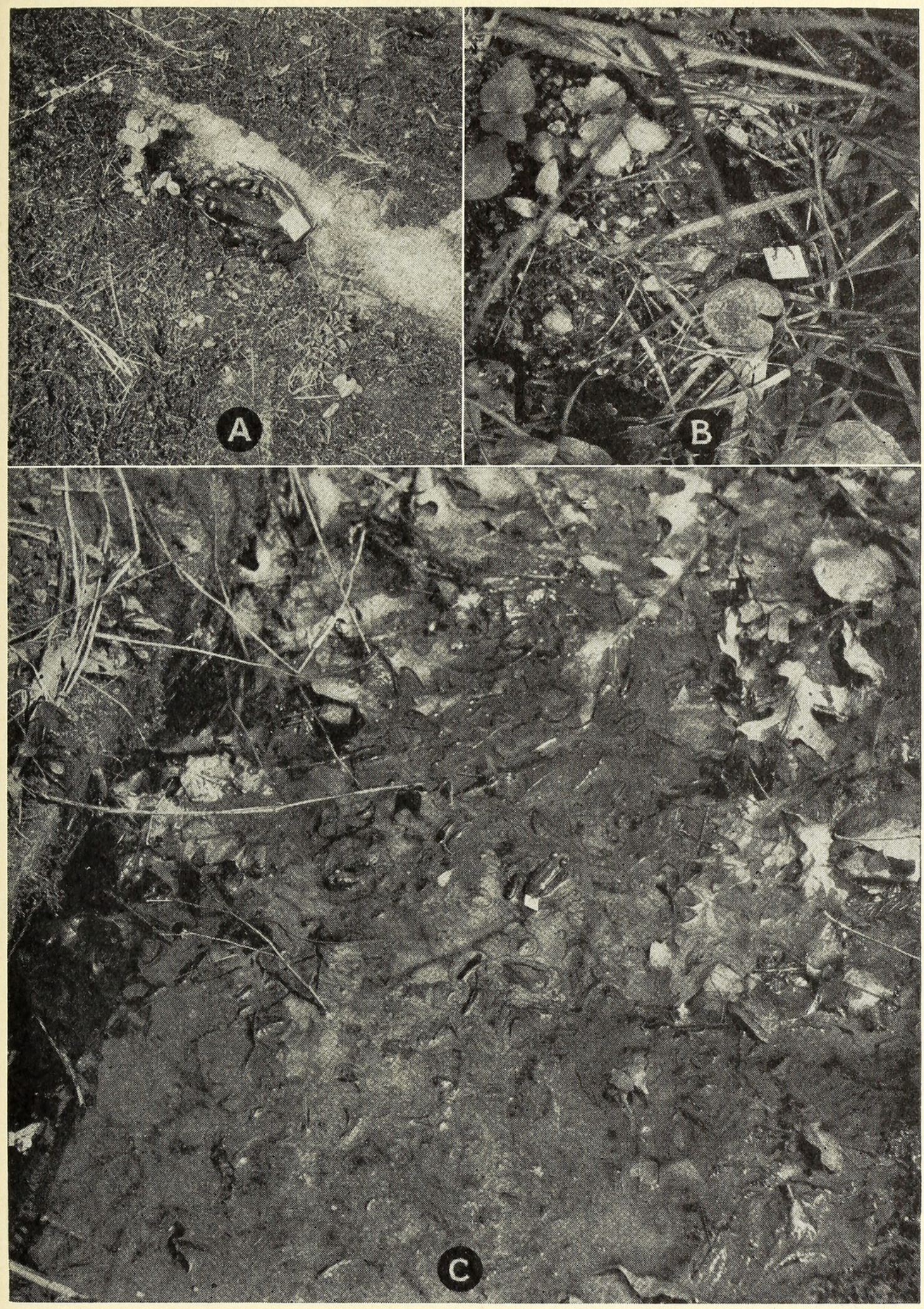

Fig. 275. Specimens of tagged Rana clamatans at Wildcat Brook; A-(B-128); $\mathrm{B}-(\mathrm{B}-129) ; \mathrm{C}-(\mathrm{B}-105$ and B-106). 
Aug. 2 In brook opposite spring.

Aug. 9 At willow tree.

Aug. 23 In brook opposite spring.

B-129 June 12 In spring.

June 13 Same place.

June 14 Same place.

June 15 Same place. (See Fig. 275-B.)

June 18 Same place. (Released 50 feet up road.'

June 19 In creek opposite spring.

June 20 Same place.

June 30 In spring.

B-131 June 13 In pool "C."

June 14 Same place.

June 18 In brook opposite spring.

June 20 Same place.

June 26 In pool "D."

Aug. 2 Between spring and ford. (F.L.'

B-132 June 13 In brook opposite pool "B."

June 14,18 and 20 Same place.

July 11 In spring.

B-133 June 13 In pool "B."

June 20 In brook opposite "B."

June 22 Across brook from pool "B."

June 29 In brook opposite "B."

July 8 Same place.

July 22 Across brook from pool "B."

Aug. 2 In brook opposite "B."

B-135 June 13 Above spring on mud flat.

June 14 Same place.

June 15 Across brook from spring.

B-137 June 14 In pool "C."

July 7 In brook about 75 feet below ford.

July 27 In brook about half way between ford and spring.

B-140 June 14 Below lower bridge opposite bog garden.

July 22 Under lower bridge.

B-141 June 14 East end of lower bridge. (Right hind foot missing.)

June 22 Same place.

June 25 (D.K.) 29, July 8, 19 in brook opposite pool "B."

July 22 East shore below lower bridge.

July 23 In pool "D."

B-142 June 14 Above spring at mud flat on a small branch.

June 15 Same place except not on branch.

June 18 and 19. Same place.

June 20 In brook opposite spring.

June 21 Above spring on mud flat.

B-143 June 15 In pool "B."

June 19 In brook opposite "B." 
June 22, 25 (D.K.), July 4 and 18 Same place.

July 22, 26, 27 and Aug. 2 Same place.

Aug. 14 In pool "B."

B-145 June 15 In brook opposite spring.

June 18 On shore opposite spring.

July 30 and August 3 At willow tree.

B-146 June 15 Across brook from spring.

June 18, 19 and 20 Same place.

July 19 At ford.

July 23 At willow tree.

July 27 In brook opposite willow tree.

Aug. 1 Across brook from pool "B."

B-147 June 15 Across brook from spring.

June 21 In brook opposite spring.

June 22 Same place. (D.K.)

July 26 At willow tree.

July 27 Same place.

B-150 June 18 In pool "C."

June 19 Same place.

July 21 In brook about 50 feet below ford.

B-153 June 20 In brook opposite pool "B."

July 27 Across brook from "B."

B-162 July 8 In brook opposite "B."

July 9 Near spring (under a board).

July 10 Same place.

July 17 In brook opposite spring.

July 22 In brook opposite pool "B" 7:00 A.M. About 50 feet above pool "B" and across brook 3:10 P.M.

July 27 In brook opposite "B."

B-163 July 9 In spring.

July 21 Same place.

July 25 At willow tree.

July 27 Across brook from willow.

July 30 In spring.

Aug. 9 At willow tree.

B-171 July 17 At ford, east shore of brook.

July 25 In brook above ford.

July 28 At willow tree.

Aug. 9 Same place.

B-174 July 22 In brook opposite pool "B."

July 23 In brook opposite spring 9:40 A.M. In pool “D” 8:45 PM.

July 25 At willow tree.

July 27 Same place.

Aug. 13 Same place.

B-175 July 18 In brook opposite pool "B."

July 22 In brook opposite bog garden.

July 25 In brook across from bog garden. 
July 27 Same place.

B-176 July 18 In brook opposite pool "B."

July 22 and Aug. 12 In pool "C."

B-180 July 23 In pool "D."

July 24, 26, Same place.

July 28 Below upper bridge.

July 30 In pool "D."

Aug. 2, 9 Same place.

Aug. 12 In pool "C."

B-181 July 23 In pool "D."

July 24 Between "D" and "C."

July 25, 26, 27, August 1, 2, 3, 9, 11, 12, 14 and 20, pool "C."

B-182 July 25 In pool "C" (had been transported some distance on July 23 from a point well back from the brook).

July 26 Same place.

July 27 In brook opposite pool "B."

B-189 Aug. 1 In pool "B."

Aug. 2 In brook 10 feet above pool "C."

B-190 Aug. 9 In pool "D."

Aug. 12 In brook opposite pool "B."

Aug. 13 In brook 15 feet below ford, 8:45 A.M.

In brook 20 feet below ford 2:30 P.M.

B-198 Aug. 12 In pool "C."

Aug. 13 At willow tree.

B-206 Aug. 18 In brook opposite spring.

Aug. 20 Below lower bridge.

F.L. and D.K. refer respectively to records made by Frank B. Lutz and Day Krolick.

A perusal of the above tabulation of activity and an examination of Fig. 274 will show at once that the voluntary movements of these frogs, more or less given to wandering, cannot be considered as a migration or even a seasonal movement induced by changing weather conditions for there is not sufficient unanimity of direction or time of movement to permit of such an interpretation. For example, some stayed in one restricted locality while others were moving up, down or across stream and in some cases must have passed each other. A study of Table II will reveal numerous instances where various frogs were moving down or across stream or staying in one place on consecutive days. For example between June 18 and 19 B-129 moved from the spring to the brook (transverse), B-116 moved from " $\mathrm{C}$ " to the ford (upstream) while B-142, 146, 149 and 150 all stayed in one place. This becomes more evident if more than a lapse of 


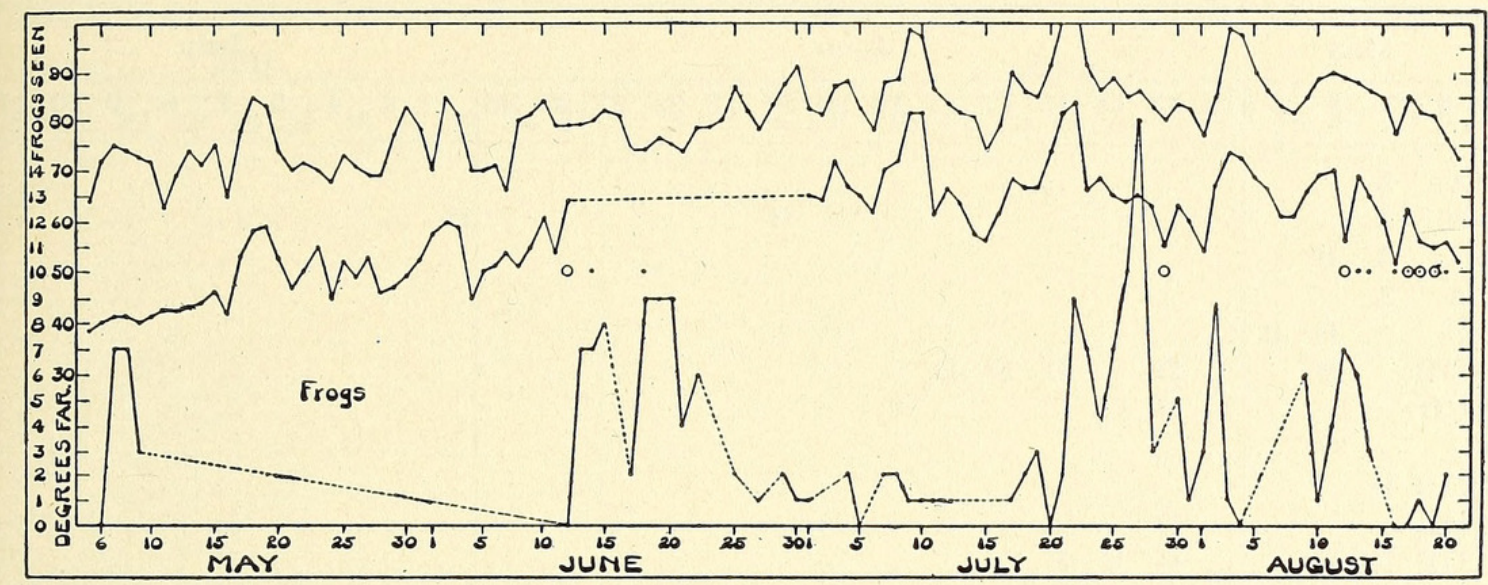

Fig. 276. Temperature (air) and number of tagged Rana clamatans seen, by days, at Interstate Park.

one day is included. From this we may tentatively infer, at least, that this species during the growing (non-sexual) period tends to remain in one place as long as its requirements are met with. Factors which may drive frogs from a site include the drying up of a pool, as happened at pool "A" which dried up in late May with the result that the frogs migrated, as far as known, to the stream. What caused one (B-106) to move so far upstream as to be opposite pool "B" we do not pretend to know. Another (B-143) which left pool " $\mathrm{B}$ " when it became nearly dry returned later when it was again filled by rain. Other adverse conditions such as a lack of food might cause similar movements but in the localities studied conditions were so uniform that this is hard to conceive of. Fright by enemies might be another, but as the handling incident to tagging failed to produce any such results, as is abundantly shown by the records, it is doubtful if the presence of enemies would do more than cause them to hide close by. Other phenomena of a less violent nature would naturally seem to have even less stimulus. To infer that they move about when they do for the pure desire to change their location is rather anthropomorphic and begs the question. Therefore we disclaim the ability to explain, as yet, these wanderings.

Another point which we are at a loss to explain is that the frogs frequently disappeared from a site for from a few hours to several days without being found elsewhere. Especial attention was paid to this point in pools "C" and "D." Although in other cases we generally avoided disturbing conditions in the case of these two they were generally "dredged" and the absence of frogs or even one 
TABLE NO. 2

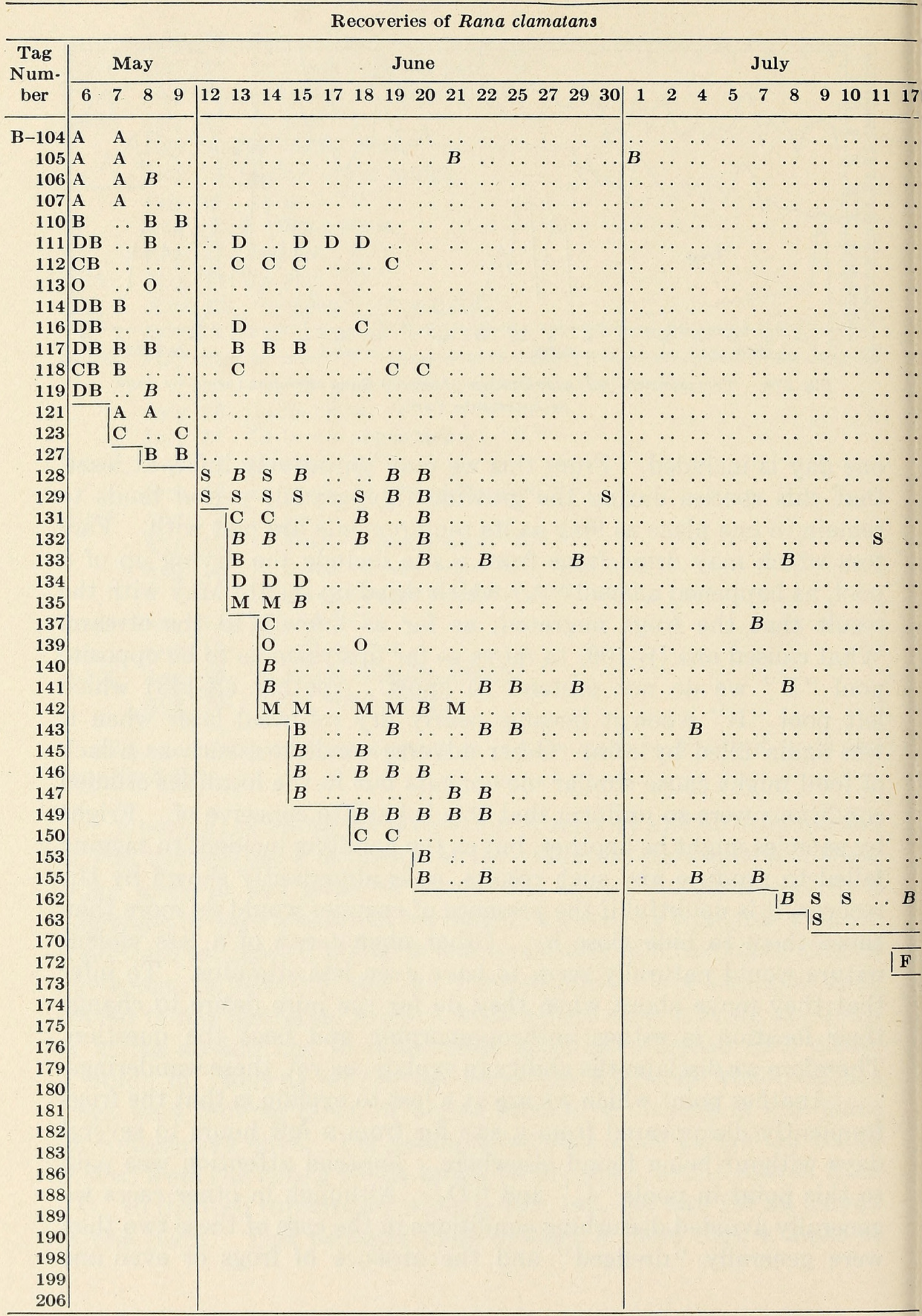

B-Brook. A-Pool "A." B-Pool "B." C-Pool "C." D-Pool "D." F-Ford. M-Mud flat. N-Across stream from Willow tree. O-Circular spring (not shown in Fig. 9). S-Spring 
TABLE NO. 2 (Cont.)

\section{Recoveries of Rana clamatus}

\section{July}

August

\begin{tabular}{|c|c|c|c|c|c|c|c|c|c|c|c|c|c|c|c|c|c|c|c|c|c|c|c|c|c|c|c|c|c|}
\hline 19 & 20 & & 22 & & & 25 & 26 & 27 & 28 & 30 & 31 & 1 & 2 & 3 & & 0 & 10 & 11 & 12 & 13 & 14 & 16 & 17 & 18 & 19 & 20 & 21 & & \\
\hline & & & & & & & & . & & & & & $\cdots$ & & $\cdots$ & $\cdots$ & & $\cdots$ & $\cdots$ & $\cdots$ & . & $\cdots$ & $\cdots$ & $\cdots$ & $\cdots$ & $\cdots$ & $\cdots$ & $\cdots$ & \\
\hline 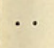 & . & $\cdots$ & $\cdots$ & $\cdots$ & $\cdots$ & . & $\cdots$ & $\cdots$ & $\cdots$ & $\cdots$ & $\cdots$ & $\cdots$ & $\cdots$ & . & . & $\cdots$ & $\cdots$ & $\cdots$ & $\cdots$ & $\cdots$ & $\cdots$ & $\cdots$ & $\cdots$ & $\cdots$ & $\cdots$ & . & $\cdots$ & $\cdots$ & $\cdots$ \\
\hline . & . & $\cdots$ & $\cdots$ & $\cdots$ & $\cdots$ & $\cdots$ & $\ldots$ & $\cdots$ & $\cdots$ & $\ldots$ & $\cdots$ & $\cdots$ & $\cdots$ & . & . & $\ldots$ & . & . & . & . & $\ldots$ & . & $\ldots$ & . & . & $\cdots$ & $\cdots$ & . & . \\
\hline . & $\ldots$ & $\ldots$ & $\cdots$ & $\ldots$ & $\cdots$ & $\ldots$ & $\cdots$ & $\ldots$ & $\cdots$ & $\ldots$ & $\cdots$ & & $\cdots$ & . & $\ldots$ & $\cdots$ & $\ldots$ & $\cdots$ & $\cdots$ & $\cdots$ & $\ldots$ & $\cdots$ & $\cdots$ & $\ldots$ & . & . & $\because$ & . & . \\
\hline . & . & $\ldots$ & $\cdots$ & $\cdots$ & $\cdots$ & $\ldots$ & $\cdots$ & $\cdots$ & $\cdots$ & $\ldots$ & . & $\ldots$ & $\ldots$ & $\cdots$ & $\ldots$ & $\ldots$ & $\cdots$ & $\cdots$ & $\ldots$ & $\ldots$ & $\ldots$ & $\cdots$ & $\ldots$ & $\ldots$ & $\cdots$ & $\cdots$ & $\cdot$ & . & . \\
\hline . & $\ldots$ & $\ldots$ & $\ldots$ & $\ldots$ & $\ldots$ & $\ldots$ & $\ldots$ & $\ldots$ & $\ldots$ & $\ldots$ & $\cdots$ & $\ldots$ & $\ldots$ & $\ldots$ & $\cdots$ & $\ldots$ & $\ldots$ & $\ldots$ & $\ldots$ & $\ldots$ & $\ldots$ & $\ldots$ & $\cdots$ & $\ldots$ & $\ldots$ & $\ldots$ & $\cdots$ & . & $\ldots$ \\
\hline & $\cdots$ & $\cdots$ & $\cdots$ & $\ldots$ & $\cdots$ & $\cdots$ & $\cdots$ & $\ldots$ & . & $\ldots$ & . & $\cdots$ & $\ldots$ & $\cdots$ & $\ldots$ & $\ldots$ & $\cdots$ & $\ldots$ & . & $\ldots$ & $\cdots$ & $\cdots$ & $\ldots$ & $\cdots$ & $\cdots$ & $\cdots$ & $\cdots$ & $\cdot$ & . \\
\hline . & $\cdots$ & $\cdots$ & $\cdots$ & $\cdots$ & $\cdots$ & $\cdots$ & $\cdots$ & $\cdots$ & $\cdots$ & $\ldots$ & . & . & $\cdots$ & $\cdots$ & $\ldots$ & $\cdots$ & . & $\ldots$ & . & $\cdots$ & . & . & . & $\ldots$ & $\ldots$ & $\cdots$ & . & . & . \\
\hline$\cdots$ & $\cdots$ & $\cdots$ & $\cdots$ & . & $\cdots$ & $\cdots$ & $\cdots$ & $\cdots$ & $\cdots$ & $\ldots$ & $\cdots$ & & $\cdots$ & $\cdots$ & $\cdots$ & $\cdots$ & $\cdots$ & $\cdots$ & $\cdots$ & $\cdots$ & $\cdots$ & $\cdots$ & $\cdots$ & • & $\cdots$ & $\cdots$ & $\cdots$ & • & . \\
\hline F & $\ldots$ & $\ldots$ & $\ldots$ & . & . & $\ldots$ & $\cdots$ & . & $\ldots$ & $\ldots$ & . & $\ldots$ & . & $\cdots$ & $\ldots$ & $\ldots$ & . & . & . & $\ldots$ & . & . & . & $\ldots$ & . & $\ldots$ & . & . & . \\
\hline . & $\cdots$ & $\cdots$ & $\ddot{ }$ & 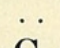 & $\ddot{C}$ & $\cdots$ & $\ddot{\sigma}$ & $\ddot{v}$ & $\ddot{\sigma}$ & $\ddot{g}$ & . & $\cdots$ & $\ddot{v}$ & $\cdots$ & . & $\cdots$ & $\ddot{a}$ & $\ddot{\mathrm{r}}$ & $\cdots$ & $\cdots$ & $\cdots$ & $\cdots$ & $\cdots$ & $\cdots$ & $\cdot$ & . & . & • & $\cdots$ \\
\hline$\cdots$ & $\ldots$ & $\ldots$ & C & C & C & $\ldots$ & C & C & C & C & . & $\ldots$ & C & . & . & $\ldots$ & C & C & . & $\ldots$ & . & . & . & & . & - & . & . & . \\
\hline . & . & . & . & . & $\ldots$ & . & . & $\ldots$ & $\cdots$ & $\ldots$ & . & $\cdots$ & $\cdots$ & . & . & $\ldots$ & $\cdots$ & . & . & $\cdots$ & . & . & $\cdots$ & $\cdots$ & $\cdots$ & $\cdots$ & $\cdots$ & $\cdots$ & $\cdots$ \\
\hline . & . & $\ldots$ & $\cdots$ & . & $\cdots$ & $\cdots$ & $\cdots$ & . & $\ldots$ & $\ldots$ & . & $\cdots$ & $\ldots$ & $\cdots$ & $\ldots$ & $\ldots$ & $\ldots$ & $\ldots$ & $\ldots$ & $\ldots$ & . & $\ldots$ & . & $\ldots$ & $\cdots$ & $\cdots$ & $\cdots$ & $\ldots$ & . \\
\hline . & $\cdots$ & . & $\cdots$ & . & $\cdots$ & $\cdots$ & . & $\ldots$ & $\cdots$ & $\ldots$ & . & $\cdots$ & . & $\cdots$ & . & $\ldots$ & . & . & . & $\ldots$ & . & . & $\cdots$ & . & $\ldots$ & $\cdots$ & . & . & . \\
\hline . & $\cdots$ & . & $\cdots$ & $\ddot{\alpha}$ & $\cdots$ & . & . & i & $\cdots$ & . & & & & . & $\ldots$ & & $\ldots$ & $\ldots$ & . & $\ldots$ & $\ldots$ & $\ldots$ & $\cdots$ & & & $\cdots$ & . & . & $\ddot{p}$ \\
\hline$\cdots$ & . & . & . & $\mathrm{S}$ & & V & WN & $\mathrm{W}$ & . & $N$ & & & $B$ & & . & & & . & & & & . & & & & & & & $B$ \\
\hline . & $\cdots$ & . & $\cdots$ & . & $\cdots$ & $\cdots$ & 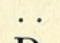 & $\cdots$ & $\cdots$ & $\ldots$ & . & . & & . & $\cdots$ & $\cdots$ & $\cdots$ & . & $\cdots$ & . & . & $\cdots$ & $\cdot$ & . & . & $\cdots$ & . & $\cdots$ & . \\
\hline$\cdots$ & $\ldots$ & $\cdots$ & $\ldots$ & . & . & . & D & . & . & . & . & $\cdots$ & F & . & $\ldots$ & . & . & . & $\ldots$ & . & . & . & . & $\ldots$ & . & . & . & . & . \\
\hline • & $\cdots$ & $\cdots$ & $\ddot{D}$ & $\cdots$ & $\cdots$ & $\cdots$ & $\cdots$ & . & $\ldots$ & $\cdots$ & • & & $\ddot{D}$ & . & $\cdots$ & $\cdots$ & $\ldots$ & $\ldots$ & . & $\ldots$ & . & $\ldots$ & $\cdots$ & . & • & $\cdots$ & · & - & $\cdots$ \\
\hline - & $\cdots$ & 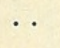 & $B$ & • & & $\cdots$ & . & . & $\cdots$ & . & - & & D & $\cdots$ & . & - & $\ldots$ & . & & & & . & . & . & $\cdots$ & $\cdots$ & $\cdots$ & . & . \\
\hline . & $\cdots$ & $\cdots$ & $\cdots$ & . & $\cdots$ & $\cdots$ & $\cdots$ & . & $\cdots$ & $\ldots$ & . & . & . & $\cdots$ & $\cdots$ & $\cdots$ & $\cdots$ & $\ldots$ & $\ldots$ & $\cdots$ & . & $\cdots$ & $\cdots$ & $\ldots$ & $\cdots$ & $\cdots$ & $\cdots$ & . & . \\
\hline . & $\cdots$ & . & . & . & $\cdots$ & $\ldots$ & $\ldots$ & . & . & . & . & & $\ldots$ & . & $\ldots$ & $\ldots$ & $\ldots$ & . & $\ldots$ & $\ldots$ & $\ldots$ & $\cdots$ & $\ldots$ & $\ldots$ & $\ldots$ & $\cdots$ & . & $\cdots$ & . \\
\hline . & . & . & $\cdots$ & . & . & $\ldots$ & . & $B$ & $\ldots$ & $\cdots$ & . & & $\ldots$ & $\cdots$ & $\cdots$ & $\cdot$ & . & $\cdots$ & $\cdots$ & $\ldots$ & . & $\cdots$ & $\cdots$ & . & $\cdots$ & $\cdots$ & . & . & . \\
\hline . & $\cdots$ & $\cdots$ & $\ddot{B}$ & $\cdots$ & $\cdots$ & $\cdots$ & . & . & $\cdots$ & $\cdots$ & - & & . & $\cdot$ & $\ldots$ & $\cdots$ & $\cdots$ & . & . & $\ldots$ & $\cdots$ & . & $\cdot$ & $\cdots$ & $\cdots$ & $\cdots$ & $\cdots$ & $\cdots$ & . \\
\hline & . & & $B$ & & & $\cdots$ & . & . & & & & & & $\cdots$ & & & $\cdots$ & & & & & & $\cdots$ & & & $\cdots$ & $\cdots$ & 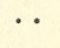 & $\cdots$ \\
\hline$B$ & $\cdots$ & . & $B$ & D & $\cdots$ & $\cdots$ & . & . & $\cdots$ & $\cdots$ & $\therefore$ & 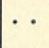 & $\cdots$ & $\cdots$ & $\cdots$ & $\cdots$ & $\cdots$ & $\cdots$ & $\cdots$ & $\therefore$ & $\cdots$ & $\cdots$ & $\cdots$ & $\cdots$ & $\cdots$ & . & $\cdots$ & $\cdots$ & . \\
\hline . & $\ldots$ & . & $\ddot{B}$ & . & & & $\ddot{B}$ & $\dot{H}$ & & $\cdots$ & & $\ldots$ & & $\ldots$ & & & & & & & & & • & . & $\cdots$ & - & $\cdots$ & $\cdots$ & $\cdots$ \\
\hline & & & & . & & & & 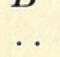 & & W & & & & W & & & & & & & & & & & & & . & & \\
\hline & $\cdots$ & & $\ldots$ & W & & & & $B$ & & & & $B$ & & & & & & & & & & & & & & & & & \\
\hline
\end{tabular}

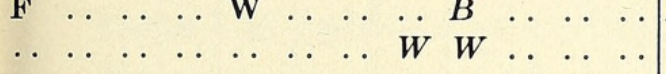

$B$

$\begin{array}{lllllll} & \ldots & \ldots & \ldots & \ldots & \ldots & \\ \ldots & \ldots & \ldots & \ldots & \end{array}$

$\begin{array}{lllllll} & B & \ldots & \ldots & \ldots & \ldots & B\end{array}$

\begin{tabular}{llllllllll}
\hline & $\ldots$ & $\ldots$ & $\ldots$ & $\mathbf{W}$ & $\ldots$ & $B$ & $\ldots$ & $\dot{s}$ & $\ldots$
\end{tabular}

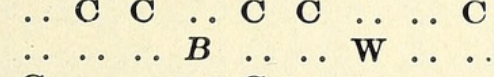
$\begin{array}{lllllllll}\mathbf{C} & \ldots & \ldots & \ldots & \mathbf{C} & \ldots & \ldots & \ldots & \ldots \\ B & B & \ldots & \mathrm{W} & \ldots & \mathrm{W} & \ldots & \ldots & \ldots\end{array}$ $\begin{array}{llllllllllllllllllll}\ldots & \ldots & \ldots & \ldots & \mathbf{W} & \ldots & \ldots & \ldots & \ldots & \ldots & \ldots & \ldots & \ldots & \ldots & \ldots & \ldots & \ldots & \ldots \\ \ldots & \ldots & \ldots & \ldots & \ldots & \ldots & \mathbf{C} & \mathbf{C} & \mathbf{C} & \ldots & \ldots & \ldots & \ldots & \ldots & \ldots & \ldots & \ldots & \ldots \\ \ldots & \ldots & \ldots & \ldots & \mathbf{W} & \ldots & \ldots & \ldots & \ldots & \ldots & \ldots & \ldots & \ldots & \ldots & \ldots & \ldots & \ldots & \ldots \\ \ldots & \ldots & \ldots & \ldots & \ldots & \ldots & \ldots & \mathbf{C} & \mathbf{C} & \ldots & \ldots & \ldots & \ldots & \ldots & \ldots & \ldots & \ldots & \ldots \\ \ldots & \ldots & \ldots & \ldots & \ldots & \ldots & \ldots & \ldots & \mathbf{W} & \ldots & \ldots & \ldots & \ldots & \ldots & \ldots & \ldots & \ldots & \ldots\end{array}$ $\begin{array}{lllllllll}B & \ldots & \ldots & B & \ldots & B & \ldots & \ldots & \ldots\end{array}$ $\begin{array}{lllllllll}C & \ldots & \ldots & \ldots & \ldots & \ldots & \ldots & \ldots & \ldots \\ \ldots & \ldots & \ldots & \ldots & B & B & \ldots & \ldots & \ldots\end{array}$

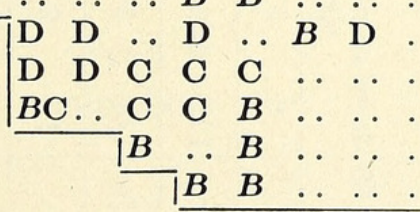

$\begin{array}{llll}B & \ldots & \ldots & \ldots\end{array}$

$\begin{array}{llllllllll}\text { C } & \mathbf{C} & \ldots & \ldots & \mathrm{C} & \ldots & \mathbf{C} & \mathbf{C} & \ldots & \mathbf{C}\end{array}$

-Base of Willow tree. For further details see text. Two localities under a date indicate those from ich and to which the individual had been moved. 

TABLE NO. 2

TABLE NO. 2 (Cont.)

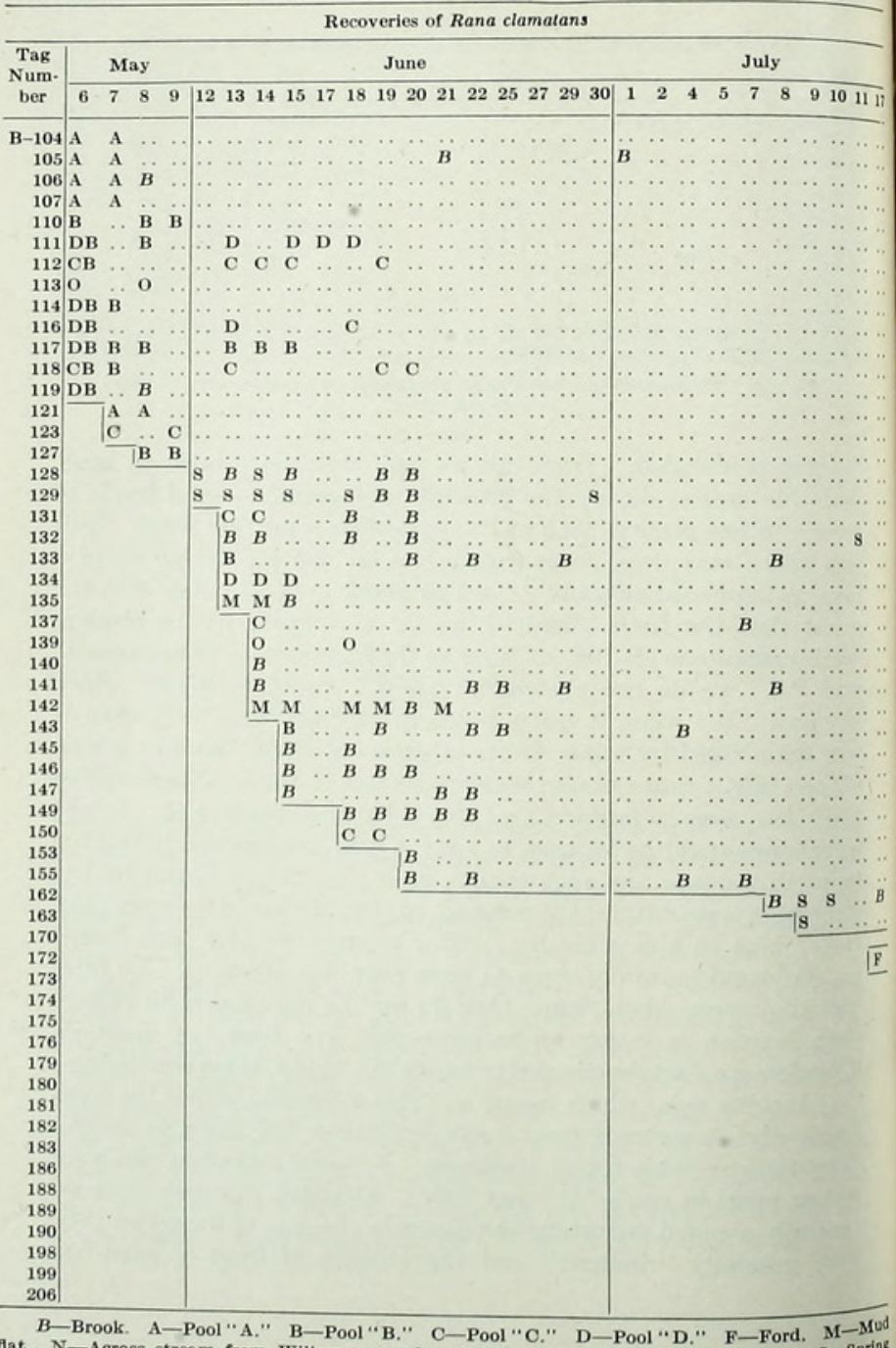

Recoveries of Rana clamatus

July August

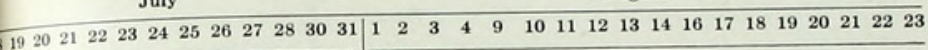

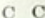

C C C

C C

WN W

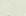

$\ddot{B}$

$B$

$\begin{array}{lll}B & D\end{array}$

B

w

$B$
$B$
$B$

w . .

B $\mathrm{w}$

B

B

B

c $c^{\mathrm{W}} \varkappa^{B} \ldots \mathrm{s}$

$\begin{array}{lllllll} & \cdots & \cdots & B & \ldots & \ldots & w\end{array}$

$\begin{array}{llllll}B & B & \ldots & \text { w } & \ldots & \text { w } \\ B & \ldots & \ldots & B & & B\end{array}$

B

$\begin{array}{lllllll}\because & \cdots & \cdots & B & B & \cdots & \\ \mathrm{D} & \mathrm{D} & \ldots & \mathrm{D} & \ldots & B & \mathrm{D} \\ \mathrm{D} & \mathrm{D} & \mathrm{C} & \mathrm{C} & \mathrm{C} & \ldots & \end{array}$

BC.. C C C $B$

$$
{ }_{B}^{B} \ldots \begin{array}{ll}
B & B \\
\hline
\end{array}
$$

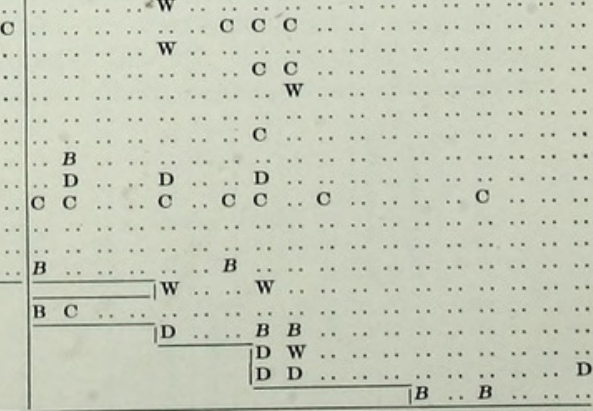

flat. N-Across stream from Willow tree, $\mathrm{O}$-Circular spring (not shown in Fig. 9), S-Spring 

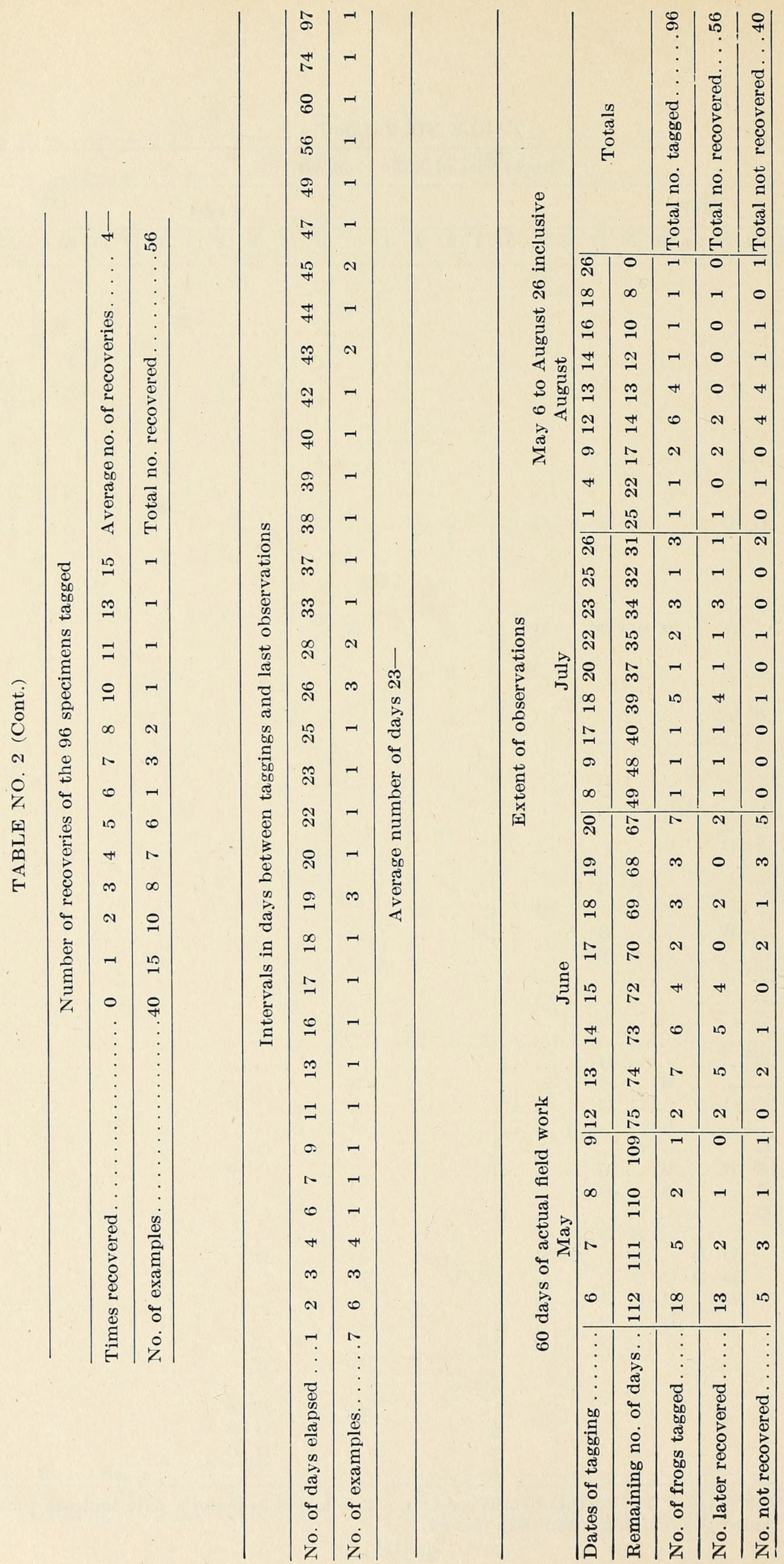
specific one is virtual evidence that they were in reality not hiding in the water or on the nearby banks. Just where they went to is still an open question. Note on Table II such frogs as B-118 in which the times it was absent from pool " $\mathrm{C}$ " for the most part actually imply just that, and not simply that by casual inspection they were not seen. Likewise B-170, B-181, etc. The impression was obtained that there was a certain periodicity to the movements of these individual frogs that caused them to hide away in inaccessable places, possibly after an extra large meal to await the processes of digestion. It will be noted that here no uniformity of disappearances or appearances was obtained. Further work alone can aid in the explanation of these phenomena.

\section{Bufo fowleri}

Although only thirty-four specimens were tagged and but twelve recovered this species yielded by far the most striking results. As the work was not of a continuous nature it may better be simply discussed by days.

On the evening of June 13, when the males were in good voice in the middle Beaver Pond, eleven were collected along its lower side (B-J to B-T). See Fig. 277. These were placed in a bag as collected and carried to the cabin where they were released about 11:00 P.M. In a few minutes after release they were all actively hopping about near the cabin and calling. This kept up until about midnight and by morning none could be found. At sunset on the 14th four of these appeared from under the cabin, began calling and were very restless. Three were not seen again and two were taken at the middle Beaver Pond not only in its general vicinity but each within a few feet of their original calling site. The remaining two were taken at Beaver Pond on the evening of June 18. This may be more clearly indicated in tabular form as follows omitting those which were not recovered at all.

\begin{tabular}{lrrrrrr} 
Frog & \multicolumn{5}{c}{ Dates-June } \\
number & 13 & 14 & 15 & 16 & 18 & 19 \\
& & C & & & B & \\
B-J & & C & & & & \\
B-K & & & & & B \\
B-L & & B & & &
\end{tabular}




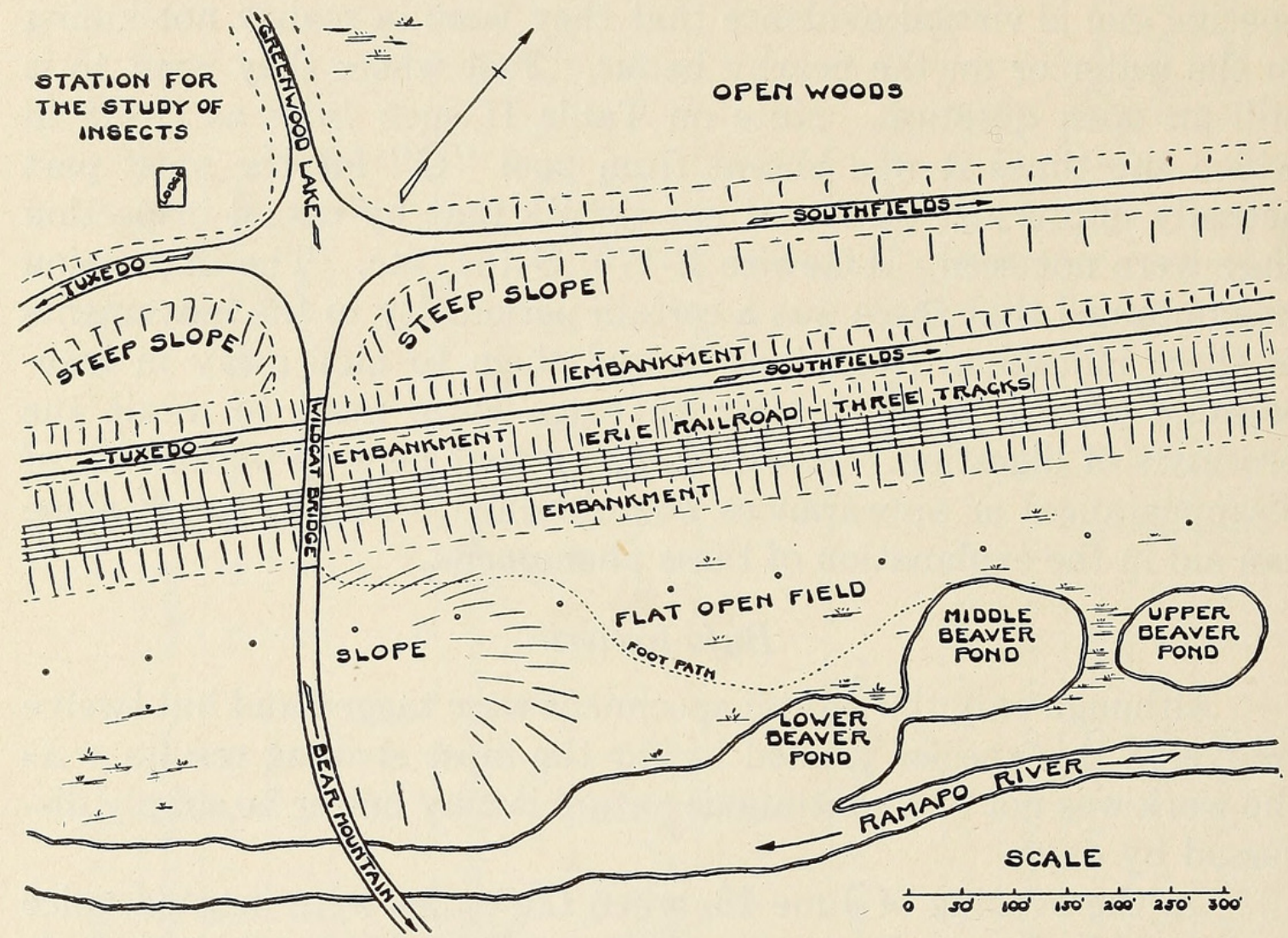

Fig. 277. Sketch map of the Beaver Ponds showing important localities.

Frog
number

B-P

$\mathrm{B}-\mathrm{Q}$

$\mathrm{B}-\mathrm{T}$

$13 \quad \begin{aligned} & 14 \\ & \text { C } \\ & \text { C } \\ & \text { B }\end{aligned}$

$\begin{array}{cccc}\text { Dates-June } & & \\ 15 & 16 & 18 & 19 \\ & & & \\ & & \text { B } & \end{array}$

"C"-At Cabin "B"-At Middle Beaver Pond.

June 13-Date of tagging. June 15, 16-Observer absent.

June 17 -No toads calling, too cool.

In other words, of the recoveries we know that at least one half got back by the 18th. The remarkable part of this performance is not the fact that it shows a degree of homing instinct for the species but is the great number of obstacles and distractions as well as the length of the journey, as is partly shown by Fig. 277. The most likely route taken by them entails a crossing of three macadam highways overcrowded at night with speeding high-powered cars and comparatively full of traffic at practically all times, the climbing of a cinder railroad embankment, the crossing of three railroad 
tracks and finally a descent into an open flat field beset with holes of small size. An alternative route would have been over Wildcat bridge which would eliminate one road crossing and the railroad but which would have lengthened their time in the path of traffic. For these reasons it was feared that possibly those that were not recovered had been crushed by passing cars although a careful search failed to reveal any remains. It is to be especially noted that the toads were headed down the opposite slope of the hill which the cabin tops toward other water where a second colony of toads were calling. These could be heard much more distinctly than those at Beaver Pond but, nervertheless, none of our tagged individuals were ever found there.

On the 14th seven more were tagged and released in a like manner (B-U to B-AA). Unfortunately none of these were recovered as it was impossible to stay at this place on the 15th and 16 th. Why none of these were recovered on the 18 th we do not know.

On the 17th one was taken and released as before but none were calling - a poor night for Bufo on account of low temperature. The next evening this one was still at the cabin.

On the 18th two more were so treated one of which B-AH was seen the next night at the cabin. Nine more were retained until the 19th before release and were not seen again but as the time available for search was slight this probably means little.

One B-184 found on July 26 not far upstream from Pool "A" has the following history.

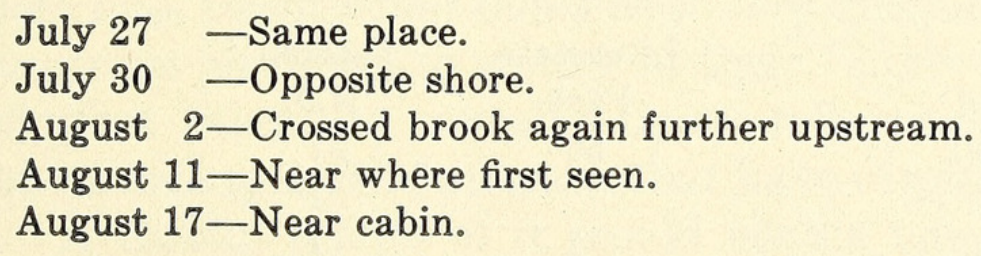

One June 18th two toads which had made the journey back to Beaver Pond (B-T and B-L) were released at the cabin along with two others which had been brought from the pond for the first time. These had "trailer" "attached to them which worked their paths. Although this device interfered with their movements somewhat it is

${ }^{1}$ This device is described in "Turtle trailing: a new technique for studying the life habits of certain testudinata." R. B. Breder Zool., Vol. IX, No. 4. The paths taken by these four toads is there illustrated. 


\section{$2 \mathrm{BHL}$ Biodiversity Heritage Library}

Breder, Charles M., Breder, Ruth B , and Redmond, Albert C . 1927. "Frog tagging: A method of studying anuran life habits." Zoologica: scientific contributions of the New York Zoological Society 9(3), 201-229. https://doi.org/10.5962/p.203743.

View This Item Online: https://www.biodiversitylibrary.org/item/208079

DOI: https://doi.org/10.5962/p.203743

Permalink: https://www.biodiversitylibrary.org/partpdf/203743

\section{Holding Institution}

Smithsonian Libraries

\section{Sponsored by}

Biodiversity Heritage Library

\section{Copyright \& Reuse}

Copyright Status: In Copyright. Digitized with the permission of the rights holder

Rights Holder: Wildlife Conservation Society

License: http://creativecommons.org/licenses/by-nc/3.0/

Rights: https://www.biodiversitylibrary.org/permissions/

This document was created from content at the Biodiversity Heritage Library, the world's largest open access digital library for biodiversity literature and archives. Visit BHL at https://www.biodiversitylibrary.org. 